Stanisław ANTAS ${ }^{1}$

\title{
METODY OBLICZEŃ PARAMETRÓW KOLEKTORA STOSOWANE W PROJEKCIE KONCEPCYJNYM SPRĘŻARKI PROMIENIOWEJ
}

\begin{abstract}
W wielu konstrukcjach jednostopniowych sprężarek odśrodkowych oraz osiowopromieniowych lotniczych silników śmigłowych i śmigłowcowych w celu zmniejszenia prędkości oraz zwiększenia ciśnienia statycznego strumienia powietrza stosuje się odpowiednio ukształtowany kolektor umieszczony za bezłopatkowym lub łopatkowym dyfuzorem. Dyfuzor spiralny jest jednym z zasadniczych typów dyfuzorów. Kolektor stanowi kanał o różnie ukształtowanych przekrojach poprzecznych, rozszerzający się stopniowo w kierunku obrotu wirnika i obejmujący poprzedzający dyfuzor walcowym otworem wlotowym. W celu zapewnienia prawidłowej pracy dyfuzora spiralnego jego parametry geometryczne winny być odpowiednio dobrane. W pracy przedstawiono dwie zasadnicze metody obliczeń parametrów geometrycznych dyfuzora spiralnego: stałej cyrkulacji oraz prędkości średniej. Wymienione metody (zalecane do stosowania w projekcie koncepcyjnym sprężarki) oparto na równaniu zachowania energii - równaniu energetycznym przepływu, równaniu ciągłości, pierwszej zasadzie termodynamiki, równaniu momentu ilości ruchu Eulera, funkcjach gazodynamicznych oraz definicjach stosowanych w teorii maszyn wirnikowych. Przeprowadzono szczegółową analizę parametrów geometrycznych kolektorów różnych rodzajów konstrukcyjnych. Zaprezentowano także przegląd wyników badań eksperymentalnych współczynnika strat przepływu w kolektorze oraz propozycję sposobu wyznaczania parametrów strumienia na wylocie spirali zbiorczej.
\end{abstract}

Słowa kluczowe: silnik turbinowy, sprężarka, kolektor

\section{Oznaczenia}

$a$ - prędkość dźwięku

$b$ - szerokość dyfuzora bezłopatkowego, łopatkowego lub kolektora

$c$ - prędkość bezwzględna

$c_{r}$ - składowa promieniowa prędkości bezwzględnej

$c_{u}$ - składowa obwodowa prędkości bezwzględnej

$D$ - średnica kanału kolektora wlotowego

$F$ - pole powierzchni

\footnotetext{
${ }^{1}$ Autor do korespondencji/corresponding author: Stanisław Antas, Politechnika Rzeszowska, al. Powstańców Warszawy 8, 35-959 Rzeszów, tel.: 17865 1501, e-mail: santas@prz.edu.pl
} 
$F_{\varphi}$ - pole powierzchni kolektora w przekroju promieniowym o współrzędnej $\varphi$

$h$ - wysokość kolektora

$\dot{m}$ - strumień masy

$n$ - wykładnik politropy/prędkość obrotowa

$p \quad$ - ciśnienie statyczne

$r$ - promień kanału kolektora kołowego w przekroju promieniowym

$R$ - promień elementarnego wycinka przekroju kanału kolektora mierzony od osi obrotu wirnika

$R_{s \mathrm{r}}$ - promień osi (środkowej) kolektora, mierzony od osi obrotu wirnika do środka ciężkości przekroju

$T$ - temperatura statyczna

$\alpha \quad$ - kąt kierunkowy prędkości bezwzględnej

$\Delta$ - wysokość progu

$\rho \quad$ - gęstość

$\lambda \quad$ - liczba Lavala

$\varphi \quad$ - kąt środkowy (azymut) liczony od języczka spirali w kierunku obrotu wirnika do rozpatrywanego przekroju promieniowego

$\xi_{s p}$ - współczynnik strat przepływu

$\vartheta \quad$ - kąt rozwarcia ścianek bocznych kolektora

\section{Indeksy}

2 - wylot wirnika

3 - wylot dyfuzora bezłopatkowego

4 - wylot dyfuzora łopatkowego

5 - wylot kolektora

6 - wylot dyfuzora stożkowego

/kr - krytyczny

/śr - średni

/SR - parametr sprężarki promieniowej

/w - wewnętrzny

Iz - zewnętrzny

*/ - parametr spiętrzenia

\section{Wprowadzenie}

W wirniku sprężarki odśrodkowej do czynnika roboczego doprowadzana jest praca efektywna, w której duży udział stanowi przyrost energii kinetycznej strumienia $\left(c_{2}>>c_{1}\right)$. Przy sprężu sprężarki $\pi_{S R}^{*} \approx 4$ prędkość bezwzględna na wylocie wirnika sięga wartości $c_{2} \approx 420 \mathrm{~m} / \mathrm{s}\left(M_{c 2} \approx 1,1\right)$, natomiast w przypadku wyższych wartości sprężu $\pi_{S R}^{*} \approx 8,5$ prędkość bezwzględna jest wyższa i wynosi $c_{2} \approx 525 \mathrm{~m} / \mathrm{s}$ co odpowiada liczbie Macha $M_{c 2} \approx 1,2$. Naddźwiękowe prędkości wypływu z wirnika wymagają zastosowania w konstrukcji sprężarki promie- 
niowej efektywnie działających dyfuzorów w celu wyhamowania strumienia powietrza do prędkości niezbędnych ze względu na prawidłowe działanie komory spalania - zwykle $c_{K S} \leq 120 \div 160 \mathrm{~m} / \mathrm{s}\left(0,1<M_{K S} \leq 0,3\right)$. Dyfuzor spiralny zwany kolektorem lub spiralą zbiorczą (rys. 1) jest klasycznym rozwiązaniem konstrukcyjnym dyfuzora, który można spotkać w szeregu konstrukcjach lotniczych silników turbinowych śmigłowych (Allison 250 - B15, Allison 250 - B17) i śmigłowcowych (GTD - 350, Allison 250 - C20) ze sprężarką osiowo - odśrodkową oraz w silnikach śmigłowych (RR500TP) i śmigłowcowych zawierających jednostopniowe sprężarki promieniowe (Allison 250 - C28, Allison 250 - C30, RR300).

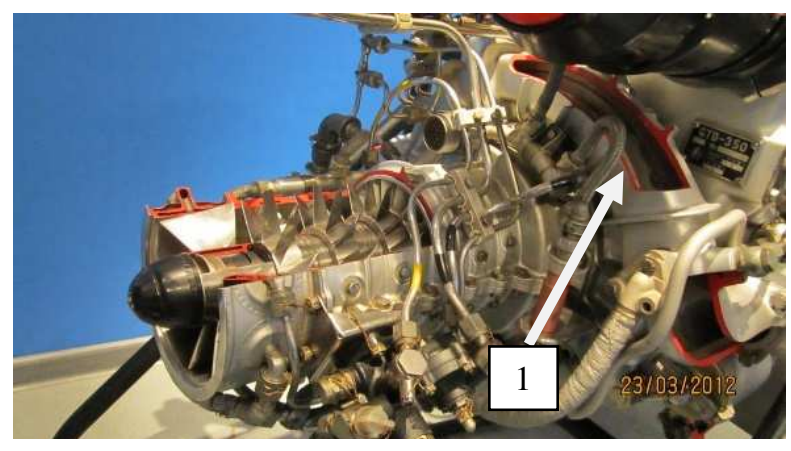

Rys. 1. Sprężarka osiowo - odśrodkowa silnika śmigłowcowego GTD-350 - przekazanego do Politechniki Rzeszowskiej przez WSK PZL Rzeszów: 1 - kolektor (dwustrumieniowy)

Fig. 1. Combined axial-centrifugal compressor of propeller engine GTD-350 - a gift from WSK PZL Rzeszów to the Rzeszow University of Technology: 1 - double jet collector

W przypadku niskiej wartości sprężu części promieniowej sprężarki $\pi_{S R}^{*}<2,5$ kolektor jest poprzedzony dyfuzorem bezłopatkowym. Przy wyższych wartościach sprężu $\pi_{S R}^{*}>2,5$ dyfuzor spiralny umieszczany jest za dyfuzorem łopatkowym poprzedzonym dyfuzorem bezłopatkowym [2]. W praktyce projektowej stosuje się dwie zasadnicze metody obliczeń parametrów geometrycznych kolektorów [16, 21]:

1) metoda bazująca na założeniu stałej wartości momentu ilości ruchu strumienia przepływającego przez spiralę (przepływ bez tarcia - stała cyrkulacja),

2) metoda oparta na założeniu przebiegu średniej prędkości strumienia w kolektorze.

Wymienione powyżej metody zakładają osiowosymetryczny charakter przepływu.

Należy zaznaczyć, że w dostępnej literaturze przedmiotu brak zarówno publikacji dotyczących kompleksowej analizy parametrów geometrycznych kolek- 
torów jak i wyznaczania parametrów termicznych i kinematycznych strumienia przepływającego przez ten dyfuzor $[3,8,11,12,15,19,21]$. Według autorów pracy [18] dyfuzor spiralny jest prawdopodobnie najbardziej zaniedbanym komponentem sprężarki promieniowej zarówno w odniesieniu do badań teoretycznych jak i eksperymentalnych. Parametry geometryczne kolektora stanowią (rys. 2-8):

- promień wewnętrzny spirali, równy promieniowi zewnętrznemu dyfuzora poprzedzającego - bezłopatkowego: $R_{w}=R_{3}=D_{3} / 2$ lub łopatkowego: $R_{w}=R_{4}=D_{4} / 2$,

- promień zewnętrzny: $R_{z}=R_{z}(\varphi)=v a r$

- promień osi (środkowej) kolektora przechodzącej przez środki ciężkości przekroju: $R_{s r}=R_{s r}(\varphi)=$ var.

Wszystkie wymienione powyżej promienie mierzone są od osi obrotu wirnika.

- szerokość lub cięciwa dyfuzora spiralnego: $b=i d e m$ lub: $b=b(\varphi)=v a r$,

- wysokość spirali zbiorczej: $h=h(\varphi)=v a r$.

Kolektor jest kanałem o różnie ukształtowanych przekrojach poprzecznych, który rozszerza się stopniowo w kierunku obrotu wirnika (tj. dyfuzorowym) o osi spiralnej okalającej dyfuzor szczelinowy lub łopatkowy. W praktyce najczęściej stosuje się kolektory [6]:

- jednostrumieniowe - czyli takie, w których jedna spirala zbiorcza obejmuje dyfuzor wzdłuż obwodu tj. $\mathrm{z}$ kątem środkowym $\varphi=2 \pi=360^{\circ}$.

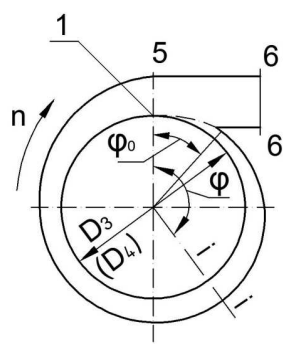

Rys. 2. Kolektor jednostrumieniowy (spirala zbiorcza pojedyncza)

Fig. 2. Single jet collector (single cumulative spiral)

- dwustrumieniowe - czyli takie, w których na obwodzie dyfuzora umieszczone są dwa kolektory przy czym każdy z nich obejmuje połowę obwodu z kątem środkowym $\varphi=2 \pi / 2=180^{\circ}$, dzieląc wydatek powietrza w tym samym stosunku.

Na rys. 2 oraz 3 „1” oznacza początkowy odcinek kolektora umieszczony na promieniu $R_{3}$ lub ewentualnie $R_{4}$, który ma współrzędną $\varphi=0$. W zależności od położenia obrysu ścianek kolektora względem osi dyfuzora bezłopatkowego lub bezłopatkowego i łopatkowego wyróżnia się następujące spirale zbiorcze (rys. 4):

- symetryczne,

- niesymetryczne. 
Rys. 3. Kolektor dwustrumieniowy (spirala zbiorcza podwójna)

Fig. 3. Double jet collector (double cumulative spiral)

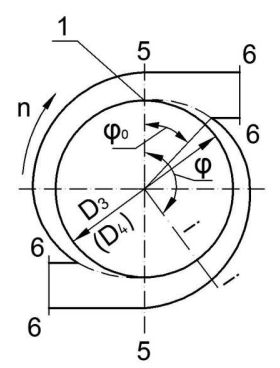

Przy projektowaniu kolektorów dąży się do tego, aby wzdłuż przekroju wlotowego kolektora ciśnienie statyczne miało w przybliżeniu wartość stałą. Spełnienie tego warunku odgrywa ważną rolę w pracy sprężarki, zwłaszcza wtedy, gdy przed kolektorem znajduje się wieniec łopatkowy dyfuzora lub koła wirnikowego. W przeciwnym, bowiem przypadku w przepływie wytworzą się pulsacje, które spowodować mogą oderwania strumienia i związane z tym znaczne straty, a na dodatek drgania łopatek dyfuzora lub koła wirnikowego, zagrażające pewności pracy sprężarki [17].

Rys. 4. Formy przekrojów promieniowych kolektora (i-i): a - symetryczny o przekroju owalnym, b - symetryczny o przekroju kołowym, c - niesymetryczny o przekroju kołowym lub prostokątnym

Fig. 4. Shapes of radial sections of the collector (i-i): a - symmetrical with an oval section, b - symmetrical with a circular section, $\mathrm{c}$ - asymmetric with a circular or rectangular section

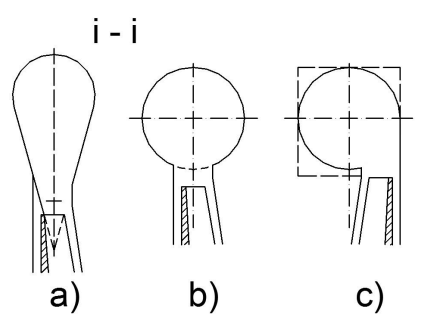

\section{Metoda stałej cyrkulacji}

Jeśli przyjmiemy, że przepływ ma charakter osiowosymetryczny oraz odbywa się bez tarcia, wówczas zgodnie z równaniem Eulera moment ilości ruchu będzie stały, a zmianę składowej prędkości bezwzględnej na kierunku unoszenia można wyznaczyć ze wzoru:

$$
C_{u} R=C_{4 u} R_{4}=K=i d e m
$$

- gdy sprężarka zawiera dyfuzor łopatkowy - lub:

$$
C_{u} R=C_{3 u} R_{3}=K=i d e m
$$

- gdy sprężarka zawiera jedynie dyfuzor bezłopatkowy.

Czynnik wypływający z dyfuzora szczelinowego lub łopatkowego zbierany jest w kolektorze począwszy od przekroju o współrzędnej $\varphi=0$. Przez promie- 
niowy przekrój kolektora (i-i) o współrzędnej $\varphi$ [rad] przepływa strumień masy zależny od miejsca posadowienia w sprężarce:

- gdy przed dyfuzorem spiralnym znajduje się dyfuzor łopatkowy

$$
\dot{m}_{\varphi}=\dot{m} \frac{\varphi}{2 \pi}=2 \pi R_{4} b_{4} c_{4 r} \rho_{4} \frac{\varphi}{2 \pi}
$$

- lub, gdy dyfuzor spiralny umieszczany jest za dyfuzorem bezłopatkowym

$$
\dot{m}_{\varphi}=\dot{m} \frac{\varphi}{2 \pi}=2 \pi R_{3} b_{3} c_{3 r} \rho_{3} \frac{\varphi}{2 \pi}
$$

Rozpatrujemy przepływ przez kolektor zabudowany bezpośrednio za dyfuzorem bezłopatkowym (szczelinowym). Bierzemy pod uwagę różne typy konstrukcyjne kolektora.

\subsection{Kolektor kołowy}

Strumień masy powietrza przepływającego przez promieniowy przekrój kolektora o współrzędnej $\varphi$ można zapisać przy użyciu składowej obwodowej $C_{u}$ prędkości bezwzględnej strumienia w kolektorze, przekroju kolektora $\mathrm{F}=\pi \mathrm{r}^{2}$ i gęstości $\rho_{3}$, którą przyjmujemy stałą dla całego przekroju $F$. Wówczas (rys. 5):

$$
\dot{m}_{\varphi}=\rho_{3} \iint_{F} C_{u} d F=\rho_{3} \iint_{F} C_{u} R \frac{d F}{R}=\rho_{3} C_{3 u} R_{3} \int_{R_{3}}^{R_{z}} \frac{b(r) d R}{R}=K \rho_{3} \int_{R_{3}}^{R_{z}} \frac{b(r) d R}{R}
$$

Zatem można zapisać:

$$
\dot{m}_{\varphi}=\dot{m} \frac{\varphi}{2 \pi}=K \rho_{3} \int_{R_{3}}^{R_{z}} \frac{b(r) d R}{R}
$$

stąd:

$$
\varphi=\frac{2 \pi}{\dot{m}} K \rho_{3} \int_{R_{3}}^{R_{z}} \frac{b(r) d R}{R}
$$

Oznaczając przez ,r" promień przekroju poprzecznego kolektora, związek między cięciwą $b$ i promieniem (rys. 6) ma postać: $(b / 2)^{2}+c^{2}=r^{2}$, gdzie: $c=\left(R-R_{3}-r\right)$, skąd:

$$
\left(\frac{b}{2}\right)^{2}=r^{2}-\left(R-R_{3}-r\right)^{2}
$$


lub:

$$
b=2 \sqrt{r^{2}-\left(R-R_{3}-r\right)^{2}}
$$

Rys. 5. Schemat oznaczeń w kolektorze kołowym sprężarki promieniowej: $R_{\dot{s} r}$ - promień osi spirali, $R_{3}$ - promień wewnętrzny kolektora $\left(R_{3}=\right.$ idem), $R_{z}$ - promień zewnętrzny kolektora $\left(R_{z}=\right.$ var $), b(r)$ - cięciwa kolektora, $r$ - promień przekroju poprzecznego kolektora

Fig. 5. Schematic markings in the circular collector of radial compressor: $R_{s}$ - radius of the spiral axis, $R_{3}$ - inner radius of the collector $\left(R_{3}=\right.$ idem $), R_{z}$ - outer radius of the collector $\left(R_{z}=\right.$ var $), b(r)$ - chord of the collector, $r$ - the radius of the collector cross-section

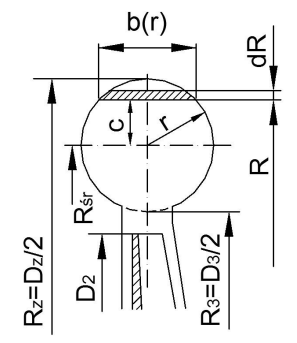

Rys. 6. Kolektor spiralny o przekroju kołowym Fig. 6. Spiral collector with a circular section

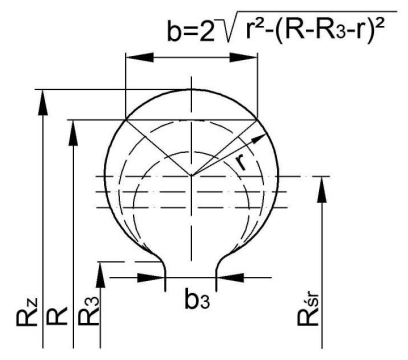

Zatem:

$$
\begin{aligned}
\varphi= & \frac{2 \pi}{\dot{m}} K \rho_{3} \int_{R_{3}}^{R_{z}} \frac{2 \sqrt{r^{2}-\left(R-R_{3}-r\right)^{2}}}{R} d R=\frac{2 \pi}{\dot{m}} K \rho_{3} \int_{R_{3}}^{R_{3}+2 r} \frac{2 \sqrt{r^{2}-\left(R-R_{3}-r\right)^{2}}}{R} d R= \\
= & \frac{4 \pi^{2}}{\dot{m}} K \rho_{3}\left[\left(R_{3}+r\right)-\sqrt{\left(R_{3}+r\right)^{2}-r^{2}}\right]
\end{aligned}
$$

Równanie powyższe, uzyskane w rezultacie szeregu złożonych przekształceń, określa zależność między kątem $\varphi$, a promieniem przekroju kołowego $r$, a więc również kształt kolektora. Rozwiązując powyższe równanie kwadratowe względem ,r", otrzymujemy:

$$
r=\frac{\varphi \cdot \dot{m}}{4 \pi^{2} K \rho_{3}}+\sqrt{R_{3} \frac{\varphi \cdot \dot{m}}{2 \pi^{2} K \rho_{3}}}
$$

Zadając wartość kąta $\varphi$, znajduje się stąd promień $r$ (kąt zadajemy w [rad]). Jeżeli kąt $\varphi$ w relacji (11) wyrażamy w stopniach, wówczas:

$$
\varphi^{\circ}=57,3 \cdot \varphi
$$


zaś formuła (11) na promień przekroju poprzecznego kolektora ma postać:

$$
r=\frac{\varphi^{\circ} \dot{m}}{4 \pi^{2} K \rho_{3} \cdot 57,3}+\sqrt{R_{3} \frac{\varphi^{\circ} \dot{m}}{2 \pi^{2} K \rho_{3} \cdot 57,3}}
$$

Dla przypadku, gdy kąt $\varphi \mathrm{w}$ równaniu (11) wyrażony jest w radianach, średnica kolektora o przekroju kołowym:

$$
D=2 r=\frac{\varphi \dot{m}}{2 \pi^{2} K \rho_{3}}+\sqrt{2 R_{3} \frac{\varphi \dot{m}}{\pi^{2} K \rho_{3}}}
$$

Natomiast, gdy kąt $\varphi$ wyrażony jest w stopniach:

$$
D=2 r=\frac{\dot{\varphi}^{\circ} \dot{m}}{2 \pi^{2} K \rho_{3} \cdot 57,3}+\sqrt{2 R_{3} \frac{\varphi^{\circ} \dot{m}}{\pi^{2} K \rho_{3} \cdot 57,3}}
$$

Promień zewnętrzny kolektora $\mathrm{w}$ dowolnym przekroju (i-i):

$$
R_{z}=R_{3}+D
$$

Jeśli spirala zbiorcza jest poprzedzona dyfuzorem łopatkowym, wówczas w powyższych relacjach należy podstawić:

$$
\begin{aligned}
& R_{3} \equiv R_{4} \\
& \rho_{3} \equiv \rho_{4} \\
& K=C_{4 u} R_{4} \\
& \dot{m}=2 \pi R_{4} b_{4} c_{4 r} \rho_{4}
\end{aligned}
$$

Promień osi (środkowej) spirali wynosi odpowiednio:

$$
R_{s r}=R_{3}+r
$$

lub gdy kolektor o przekroju kołowym jest poprzedzony dyfuzorem łopatkowym:

$$
R_{s r}=R_{4}+r
$$

\subsection{Kolektor o stałej szerokości (prostokątny)}

W tym wypadku $b(r)=b=i d e m$ (rys. 7). Wobec tego wzór (7) na kąt $\varphi$ wyrażony w radianach ma postać: 


$$
\begin{aligned}
\varphi=\frac{2 \pi}{\dot{m}} K \rho_{3} \int_{R_{3}}^{R_{z}} \frac{b(r) d R}{R}=\frac{2 \pi}{\dot{m}} K \rho_{3} b \ln R_{R_{3}}^{R_{z}}= \\
=\frac{2 \pi}{\dot{m}} K \rho_{3} b\left(\ln R_{z}-\ln R_{3}\right)=\frac{2 \pi}{\dot{m}} K \rho_{3} b \ln \frac{R_{z}}{R_{3}}
\end{aligned}
$$

stąd:

$$
\frac{R_{z}}{R_{3}}=e^{\frac{\dot{m} \varphi}{2 \pi K b \rho_{3}}}
$$

i ostatecznie:

$$
R_{Z}=R_{3} e^{\frac{\dot{m} \varphi}{2 \pi K b \rho_{3}}}
$$

Zatem krzywa wyznaczająca zarys zewnętrzny dyfuzora spiralnego jest w tym przypadku spiralą logarytmiczną.

Rys. 7. Kolektor spiralny o przekroju prostokątnym

Fig. 7. Spiral collector with a rectangular sectio

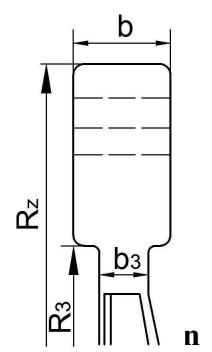

Ponieważ zgodnie z formułą (23):

$$
\varphi=\frac{2 \pi}{\dot{m}} K \rho_{3} b \ln \frac{R_{z}}{R_{3}}
$$

oraz korzystając ze wzoru (2) (lub (1)) i ze wzoru:

$$
\dot{m}=2 \pi R_{3} b_{3} C_{3 r} \rho_{3}
$$

lub relacji (20):

$$
\dot{m}=2 \pi R_{4} b_{4} C_{4 r} \rho_{4}
$$

mamy:

$$
\varphi=\frac{2 \pi R_{3} b C_{3 u} \rho_{3}}{2 \pi R_{3} b_{3} C_{3 r} \rho_{3}} \ln \frac{R_{z}}{R_{3}}=\frac{C_{3 u} b}{C_{3 r} b_{3}} \ln \frac{R_{z}}{R_{3}}
$$


lecz:

$$
\ln x \cong 2,3 \log x
$$

więc:

$$
\varphi \cong 2,3 \frac{C_{3 u} b}{C_{3 r} b_{3}} \log \frac{R_{z}}{R_{3}}
$$

lub w stopniach:

$$
\varphi^{\circ}=57,3 \cdot \varphi \cong 132 \frac{C_{3 u} b}{C_{3 r} b_{3}} \log \frac{R_{z}}{R_{3}}
$$

Jeśli kolektor spiralny jest poprzedzony dyfuzorem łopatkowym otrzymuje się odpowiednio relacje:

$$
R_{Z}=R_{4} e^{\frac{\dot{m} \varphi}{2 \pi K b \rho_{4}}}
$$

gdzie: $K=C_{4 u} R_{4}, \dot{m}=2 \pi R_{4} b_{4} C_{4 r} \rho_{4}$

oraz:

$$
\begin{aligned}
& \varphi=\frac{2 \pi}{\dot{m}} K \rho_{4} b \ln \frac{R_{z}}{R_{4}} \\
& \varphi=\frac{C_{4 u} b}{C_{4 r} b_{4}} \ln \frac{R_{z}}{R_{4}} \\
& \varphi \cong 2,3 \frac{C_{4 u} b}{C_{4 r} b_{4}} \log \frac{R_{z}}{R_{4}} \\
& \varphi^{\circ}=132 \frac{C_{4 u} b}{C_{4 r} b_{4}} \log \frac{R_{z}}{R_{4}}
\end{aligned}
$$

Wzór (25) można uprościć poprzez rozwinięcie go w szereg, a wówczas mamy:

$$
R_{z}=R_{3}\left[1+\frac{\dot{m}}{2 \pi K b \rho_{3}} \varphi+\left(\frac{\dot{m}}{2 \pi K b \rho_{3}}\right)^{2} \frac{\varphi^{2}}{2}+\cdots\right]
$$

pomijając wyrażenia w potędze większej od jedności (małe wyższego rzędu):

$$
R_{z}=R_{3}+R_{3} \frac{\dot{m}}{2 \pi K b \rho_{3}} \varphi
$$

lub po uwzględnieniu wzorów (2) i (26): 


$$
R_{z}=R_{3}+R_{3} \frac{C_{3 r} b}{C_{3 u} b_{3}} \varphi
$$

skąd:

$$
\varphi \cong \frac{R_{z}-R_{3}}{R_{3}} \frac{C_{3 u} b}{C_{3 r} b_{3}}
$$

lub wyrażony w stopniach:

$$
\varphi^{\circ}=57,3 \frac{R_{z}-R_{3}}{R_{3}} \frac{C_{3 u} b}{C_{3 r} b_{3}}
$$

Wzór (37) daje wyniki mniej dokładne i przedstawia spiralę Archimedesa. Promień osi środkowej spirali o przekroju prostokątnym.

$$
R_{s r}=R_{3}+\frac{R_{z}-R_{3}}{2}=\frac{R_{z}-R_{3}}{2}
$$

\subsection{Kolektor o przekroju kwadratowym}

Dla kolektora o przekroju kwadratowym (rys. 8) możemy napisać związek:

$$
b=R_{z}-R_{3}
$$

Ponieważ kąt $\varphi$ określa wzór (7):

$$
\varphi=\frac{2 \pi}{\dot{m}} K \rho_{3} \int_{R_{3}}^{R_{z}} \frac{b(r) d R}{R}
$$

stąd po uwzględnieniu zależności $b(r)=b=$ idem uzyskuje się analogicznie jak dla kolektora prostokątnego - zależność (23):

$$
\varphi=\frac{2 \pi}{\dot{m}} K \rho_{3} b \ln \frac{R_{z}}{R_{3}}
$$

oraz po uwzględnieniu formuły (42):

$$
\varphi=\frac{2 \pi}{\dot{m}} K \rho_{3}\left(R_{z}-R_{3}\right) \ln \frac{R_{z}}{R_{3}}
$$

lub w stopniach wykorzystując relację (35) dla kolektora prostokątnego: 


$$
\varphi^{\circ}=132 \frac{C_{3 u} b}{C_{3 r} b_{3}} \log \frac{R_{z}}{R_{3}}
$$

zatem, biorąc pod uwagę wyrażenie (42):

$$
\varphi^{\circ}=132 \frac{C_{3 u}\left(R_{z}-R_{3}\right)}{C_{3 r} b_{3}} \log \frac{R_{z}}{R_{3}}
$$

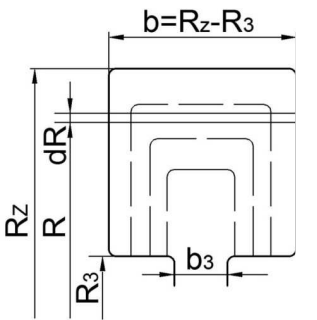

Rys. 8. Kolektor spiralny o przekroju kwadratowym

Fig. 8. Spiral collector with a square section

Szerokość (wysokość) kanału przepływowego kolektora - wzór (42) można określić przez całkowanie w przekroju wylotowym spirali $\left(b=b_{w y l}=b_{5}\right)$. Zakładając, iż w tym przekroju na promieniu osi spirali

$$
R_{5 s r}=R_{3}+b / 2
$$

przepływający strumień osiąga prędkość:

$$
C_{5 u s r}=\frac{C_{3 u} R_{3}}{R_{5 s r}}
$$

lub ogólnie:

$$
C_{u}=\frac{C_{3 u} R_{3}}{R}
$$

zaś elementarny strumień masy:

$$
d \dot{m}=\rho_{3} C_{u} b d R
$$

stąd:

$$
\dot{m}=\rho_{3} \int_{R_{3}}^{R_{z}} C_{u} b d R=\rho_{3} \int_{R_{3}}^{R_{3}+b} C_{u} b R_{3} \frac{d R}{R}
$$

zatem:

$$
\dot{m}=\rho_{3} b C_{3 u} R_{3} \ln \frac{R_{3}+b}{R_{3}} \quad \text { lub } \quad \dot{m}=K \rho_{3} b \ln \frac{R_{3}+b}{R_{3}}
$$


Równanie to rozwiązuje się metodą kolejnych przybliżeń. Wartość lewej strony równania jest bowiem znana i wynosi - wzór (26). Szerokość lub wysokość kanału przepływowego kolektora o przekroju kwadratowym można również wyznaczyć w sposób przybliżony. Uwzględniając, że w przekroju spirali (5-5) w jej osi przepływający strumień ma prędkość określoną zależnością (46), a zatem po uwzględnieniu tej formuły uzyskuje się:

$$
C_{5 u s r}=\frac{C_{3 u} R_{3}}{R_{3}+\frac{b}{2}}
$$

Strumień masy powietrza przepływającego przez ten przekrój (5-5) wynosi odpowiednio $\left(\rho_{5 s r}=\rho_{3}\right)$ :

$$
\dot{m}=\dot{m}_{5}=\rho_{3} C_{5 u s r} F_{5}
$$

więc:

$$
\dot{m}=\rho_{3} \frac{C_{3 u} R_{3}}{R_{3}+\frac{b}{2}} b^{2}
$$

$\mathrm{Z}$ drugiej strony wiadomo, iż strumień masy określa formuła (26) zatem:

$$
2 \pi R_{3} b_{3} C_{3 r}=\frac{C_{3 u} R_{3}}{R_{3}+\frac{b}{2}} b^{2}
$$

Rozwiązując powyższe równanie kwadratowe względem „,b” uzyskuje się:

$$
b=\frac{\pi}{2} b_{3} \frac{C_{3 r}}{C_{3 u}}+\sqrt{\left(\frac{\pi b_{3} c_{3 r}}{2 c_{3 u}}\right)^{2}+\left(\frac{\pi b_{3} c_{3 r}}{c_{3 u}}\right)}
$$

Uwaga: W przypadku kolektora jednostrumieniowego $\mathrm{w}$ relacjach powyższych należy uwzględnić, że: $\dot{m}=\dot{m} ; \varphi=0 \ldots 2 \pi$; lub $\varphi^{\circ}=0 \ldots 360^{\circ}$, natomiast dla kolektora dwustrumieniowego: $\dot{m}=\frac{\dot{m}}{2} ; \varphi=0 \ldots \pi ;$ lub $\varphi^{\circ}=0 \ldots 180^{\circ}$

\section{Metoda średniej prędkości strumienia}

Druga ze stosowanych metod obliczeń parametrów geometrycznych kolektorów oparta jest na założeniu przebiegu wartości średniej prędkości strumienia w rozpatrywanym przekroju dyfuzora spiralnego $[16,21]$. 


\subsection{Kolektor o przekroju trapezowym lub owalnym (gruszkowym)}

Oznaczając przekrój kolektora odpowiadający kątowi środkowemu $\varphi$ wyrażonemu w radianach przez $F_{\varphi}$, wówczas zadając wartość średniej wartości strumienia w tym przekroju, uzyskuje się dla kolektora jednostrumieniowego relację:

$$
F_{\varphi}=\frac{\dot{m}_{\varphi}}{\rho_{3} \cdot c_{s r}}
$$

lub:

$$
F_{\varphi}=\frac{\dot{m} \varphi^{\circ}}{\rho_{3} \cdot 360 \cdot c_{s r}}
$$

zaś, dla kolektora dwustrumieniowego formułę:

$$
F_{\varphi}=\frac{\dot{m} \varphi^{\circ}}{\rho_{3} \cdot 180 \cdot c_{s r}}
$$

Wyrażając pole powierzchni, jako $F_{\varphi}$ jako funkcję znanych wielkości geometrycznych tj. $F_{\varphi}=f\left(b_{3}, \vartheta, h\right)$ - dla kolektora trapezowego oraz $F_{\varphi}=f\left(b_{3}, \vartheta, h_{c}\right)-$ dla owalnego $\mathrm{z}$ równania ciągłości określa się odpowiednio wielkości $h$ oraz $h_{c}$ (rys. 9).

a)

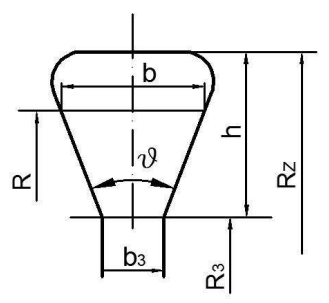

b)

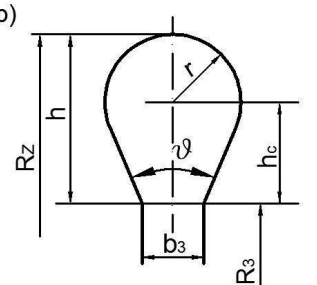

Rys. 9. Schemat oznaczeń w kolektorze trapezowym (a) oraz owalnym (b): h - wysokość kolektora, $\vartheta$ - kąt rozwarcia ścianek bocznych kolektora

Fig. 9. Schematic markings in the trapezoidal (a) and oval (b) collector: $\mathrm{h}$ - the collector height, $\vartheta$ - the angle of flare of the lateral walls of the collector

W przypadku kolektora o przekroju trapezowym wysokość kolektora $h=R_{z}-R_{3}$, odpowiadająca kątowi środkowemu $\varphi$, związana jest z przekrojem $F_{\varphi}$ równaniem kwadratowym: 


$$
F_{\varphi}=\operatorname{tg} \frac{\vartheta}{2} h^{2}+b_{3} \cdot h
$$

skąd

$$
h=-\frac{b_{3}}{2 \operatorname{tg} \frac{\vartheta}{2}}+\sqrt{\left(\frac{b_{3}}{2 \operatorname{tg} \frac{\vartheta}{2}}\right)+\frac{F_{\varphi}}{\operatorname{tg} \frac{\vartheta}{2}}}
$$

zatem, dla kolektora jednostrumieniowego uzyskuje się zależność:

$$
h=-\frac{b_{3}}{2 \operatorname{tg} \frac{\vartheta}{2}}+\sqrt{\left(\frac{b_{3}}{2 \operatorname{tg} \frac{\vartheta}{2}}\right)+\frac{\dot{m} \varphi^{\circ}}{\rho_{3} \cdot 360 \cdot c_{s r} \cdot \operatorname{tg} \frac{\vartheta}{2}}}
$$

lub:

$$
h=-K_{1}+\sqrt{K_{1}^{2}+\frac{K_{2} \varphi^{\circ}}{c_{s r}}}
$$

gdzie:

$$
\begin{aligned}
& K_{1}=\frac{b_{3}}{2 \operatorname{tg} \frac{\vartheta}{2}} \\
& K_{2}=\frac{\dot{m}}{\rho_{3} \cdot 360 \cdot \operatorname{tg} \frac{\vartheta}{2}}
\end{aligned}
$$

W celu uwzględnienia zmniejszenia pola powierzchni przekroju kolektora w rezultacie zaokrągleń naroży wprowadza się współczynnik korekcyjny $K_{F}=1,05 \div 1,1$ [16], a wówczas

$$
K_{2}=\frac{\dot{m} K_{F}}{\rho_{3} \cdot 360 \cdot \operatorname{tg} \frac{\vartheta}{2}}
$$

Szerokość dyfuzora spiralnego o zarysie trapezowym dla dowolnej wartości promienia R przekroju poprzecznego wyznacza zależność geometryczną

$$
b=b_{3}+2\left(R-R_{3}\right) \operatorname{tg} \frac{\vartheta}{2}
$$

Dla dyfuzora spiralnego o przekroju gruszkowym (rys. 9b) wartość odległości $h_{c}$ środka okręgu o promieniu $r$ od promienia wlotowego $R_{3}$, odpowiada- 
jąca kątowi środkowemu $\varphi$, związana jest z przekrojem $F_{\varphi}$ następującym równaniem kwadratowym:

$$
F_{\varphi}=\left(\frac{\pi}{2} \operatorname{tg}^{2} \frac{\vartheta}{2}+\operatorname{tg} \frac{\vartheta}{2}\right) h_{c}^{2}+\left(\frac{\pi}{2} b_{3} \operatorname{tg} \frac{\vartheta}{2}+b_{3}\right) h_{c}+\frac{\pi}{8} b_{3}^{2}
$$

Po rozwiązaniu powyższego równania kwadratowego i przekształceniach uzyskuje się odpowiednio [16]:

$$
h_{c}=-K_{1}+\sqrt{\frac{K_{1}^{2} \operatorname{tg} \frac{\vartheta}{2}+F_{\varphi}}{K_{3}}}
$$

lub, uwzględniając zależność na $F_{\varphi}$ dla kolektora jednostrumieniowego, uzyskuje się:

$$
h_{c}=-K_{1}+\sqrt{\frac{K_{1}^{2}+\frac{K_{2}^{\prime} \varphi^{\circ}}{c_{s r}}}{K_{3}}}
$$

gdzie:

$$
\begin{aligned}
& K_{1}=\frac{b_{3}}{2 \operatorname{tg} \frac{\vartheta}{2}} \\
& K_{2}^{\prime}=\frac{\dot{m}}{\rho_{3} \cdot 360} \\
& K_{3}=\frac{\pi}{2} \operatorname{tg}^{2} \frac{\vartheta}{2}+\operatorname{tg} \frac{\vartheta}{2}
\end{aligned}
$$

Pozostałe parametry geometryczne kolektora określają zależności:

$$
\begin{aligned}
& r=\left(h_{c}+K_{1}\right) \operatorname{tg} \frac{\vartheta}{2} \\
& h=h_{c}+r \\
& R_{z}=R_{3}+h
\end{aligned}
$$

\subsection{Kolektor o przekroju kołowym}

Dla dowolnego przekroju poprzecznego kolektora jednostrumieniowego przekrój

$$
F_{\varphi}=\frac{\pi D^{2}}{4}
$$


zatem według relacji (56)

$$
\frac{\pi D^{2}}{4}=\frac{\dot{m}_{\varphi}}{\rho_{3} c_{s r}}
$$

stąd średnica kolektora

$$
D=2 \sqrt{\frac{\dot{m}_{\varphi}}{\pi \rho_{3} c_{s r}}}
$$

lub zgodnie z formułą (57)

$$
\frac{\pi D^{2}}{4}=\frac{\dot{m} \varphi^{\circ}}{\rho_{3} c_{s r} 360}
$$

skąd:

$$
D=\sqrt{\frac{\dot{m} \varphi^{\circ}}{90 \pi \rho_{3} c_{s r}}}
$$

zaś dla kolektora dwustrumieniowego według (58)

$$
D=\sqrt{\frac{\dot{m} \varphi^{\circ}}{45 \pi \rho_{3} c_{s r}}}
$$

Dla kolektora zabudowanego na wylocie dyfuzora bezłopatkowego, można przyjmować wzdłuż całej spirali stałą wartość prędkości średniej strumienia $c_{s r}=(0,7 \div 0,8) c_{3}$. Zalecana wartość kąta rozwarcia ścianek bocznych kolektora trapezowego oraz owalnego zawiera się w przedziale $\vartheta=45 \div 60^{\circ}[14$, $16]$.

\section{Parametry strumienia na wylocie kolektora}

Strata ciśnienia spiętrzenia w kolektorze zależy od miejsca zabudowy dyfuzora spiralnego w kanale przepływowym sprężarki, stąd w zależności od układu konstrukcyjnego jest wyznaczania z następujących zależności:

- dla kolektora zabudowanego na wylocie koła wirnikowego (sprężarka bez dyfuzora szczelinowego i łopatkowego):

$$
\Delta p_{2,5}^{*}=\xi_{s p} \frac{\rho_{2} \cdot c_{2}^{2}}{2}
$$


- dla kolektora poprzedzonego dyfuzorem bezłopatkowym:

$$
\Delta p_{3,5}^{*}=\xi_{s p} \frac{\rho_{3} \cdot c_{3}^{2}}{2}
$$

- dla kolektora zabudowanego na wylocie dyfuzora łopatkowego:

$$
\Delta p_{4,5}^{*}=\xi_{s p} \frac{\rho_{4} \cdot c_{4}^{2}}{2}
$$

Zagadnienie określenia wartości współczynnika strat przepływu w dyfuzorze spiralnym $\xi_{\mathrm{sp}}$, ustalanego doświadczalnie, było przedmiotem rozważań jedynie nielicznych prac $[1,4,5,9,12,17,19,20]$. Według [1] wartość współczynnika strat przepływu w kolektorze (rys. 10) zależy od miejsca zabudowy dyfuzora spiralnego w kanale przepływowym sprężarki oraz od kąta napływu strumienia $\alpha\left(\alpha_{2}, \alpha_{3}\right)$ na wlocie kolektora. Ze względu na duże wartości współczynnika strat przepływu w konstrukcjach sprężarek promieniowych lotniczych silników turbinowych nie stosuje się zabudowy kolektora bezpośrednio za kołem wirnikowym.

Najbardziej kompleksową analizę przebiegów współczynnika strat przepływu w dyfuzorze spiralnym $\mathrm{w}$ funkcji kąta wypływu strumienia $\mathrm{z}$ dyfuzora bezłopatkowego $\alpha_{3}$ przedstawiono w pracy [19] - rys. 11. Wartość tego kąta związana jest z punktem pracy sprężarki od granicy pompażu $\left(\dot{m}_{\min }\right)$ do wydajności maksymalnej $\left(\dot{m}_{\max }\right)$.

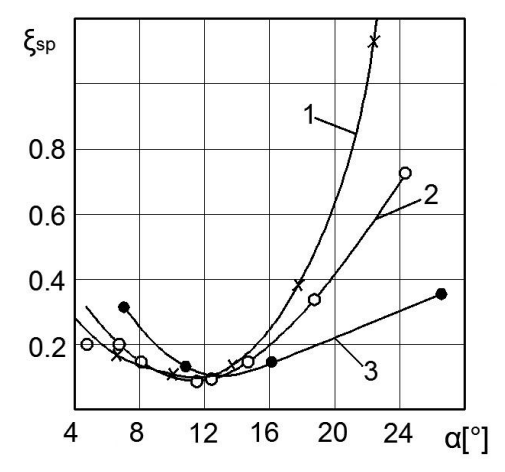

Rys. 10. Zmiany współczynnika strat przepływu w kolektorze w funkcji kąta napływu. 1, 2 - kolektor zabudowany na wylocie koła wirnikowego, 3 - kolektor poprzedzony dyfuzorem bezłopatkowym

Fig. 10. Changes of the coefficient of flow losses in the collector vs. angle of inflow. 1,2 - the collector mounted at the outlet of the impeller wheel, 3 - the collector preceded by a vaneless diffuser

$\mathrm{Z}$ analizy przebiegów przedstawionych na rys. 10 oraz rys. 11 wynika wniosek, że rozbieżności między wynikami badań poszczególnych autorów są znaczne. W celu usunięcia wątpliwości dotyczących wiarygodności rezultatów tych badań wskazane byłoby obszerne dodatkowe badania eksperymentalne bazujące na pomiarach ciśnień, temperatur i prędkości w przekrojach wlotowych i wylotowych kolektora, unikając uzupełniania badań obliczaniem prędkości w przekrojach kontrolnych. Według Tuliszki [17] współczynnik strat przepływu 
w dyfuzorze spiralnym ma stałą wartość niezależnie od kąta $\alpha_{3}$, a jego wartość jest zdecydowanie niższa. Podobne zalecenia podano w pracy [5] przy czym $\left(\xi_{\mathrm{sp}}=0,06 \div 0,15\right)$ oraz monografii $[20]\left(\mathrm{gdzie} \xi_{\mathrm{sp}}=0,22\right)$ :

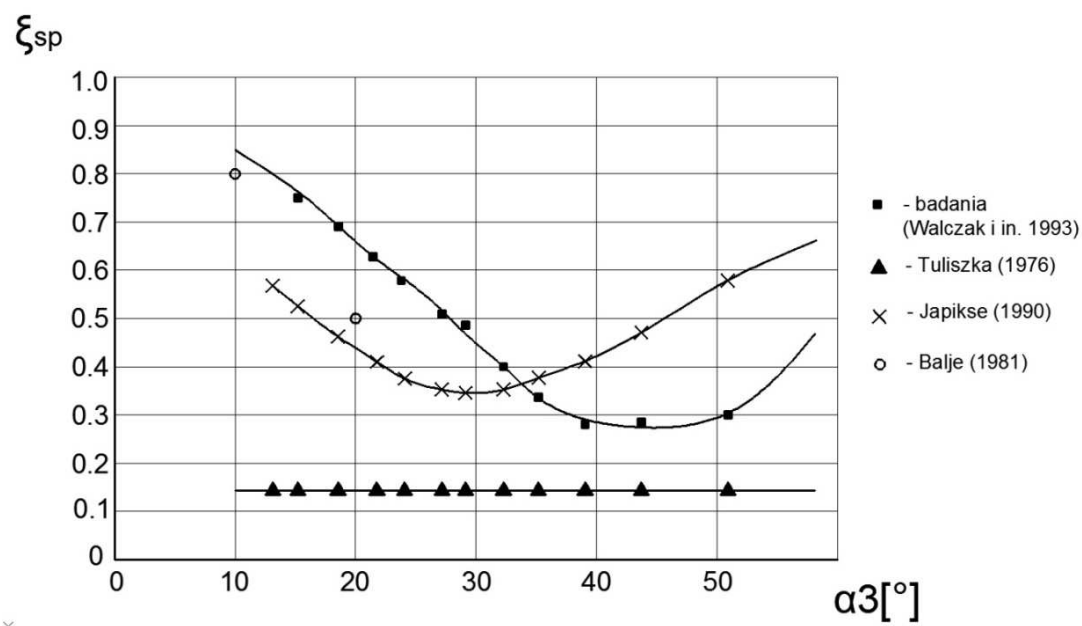

Rys. 11. Przebiegi współczynnika strat przepływu w kolektorze w funkcji kąta kierunkowego prędkości bezwzględnej $\alpha_{3}$ na wlocie kolektora [19]

Fig. 11. The variation of the coefficient of flow loss in the collector vs. direction angle of absolute velocity $\alpha_{3}$ at the collector inlet [19]

- Ciśnienie spiętrzenia $p_{5}^{*} \mathrm{w}$ przekroju wylotowym (5-5) spirali określa się w zależności od układu konstrukcyjnego sprężarki promieniowej. I tak w przypadku kolektora zabudowanego na wylocie wirnika i za dyfuzorem bezłopatkowym mamy odpowiednio

$$
\begin{aligned}
& p_{5}^{*}=p_{2}^{*}-\Delta p_{2,5}^{*} \\
& p_{5}^{*}=p_{3}^{*}-\Delta p_{3,5}^{*}
\end{aligned}
$$

zaś, dla kolektora poprzedzonego dyfuzorem łopatkowym

$p_{5}^{*}=p_{4}^{*}-\Delta p_{4,5}^{*}$

- Temperatura spiętrzenia w przekroju wylotowym

$$
T_{5}^{*}=T_{2}^{*}=T_{3}^{*}=T_{4}^{*}
$$

- Prędkość bezwzględna strumienia w przekroju wylotowym spirali poprzedzonej dyfuzorem bezłopatkowym jest określona równaniem (46): 
$c_{5}=c_{5 u s r}=\frac{c_{3 u} \cdot R_{3}}{R_{s r 5}}$

- Prędkość krytyczna dźwięku

$$
a_{k r 5}=\sqrt{\frac{2 \cdot k \cdot R}{k+1} T_{5}^{*}}
$$

- Liczba Lavala prędkości wypływu strumienia z kolektora

$$
\lambda_{5}=\frac{c_{5}}{a_{k r 5}}
$$

- Funkcja gazodynamiczna ciśnienia

$$
\Pi\left(\lambda_{5}\right)=\left(1-\frac{k-1}{k+1} \lambda_{5}^{2}\right)^{\frac{k}{k-1}}
$$

- Ciśnienie statyczne

$$
p_{5} \equiv p_{\varphi=2 \pi}=\Pi\left(\lambda_{5}\right) \cdot p_{5}^{*}
$$

- Temperatura statyczna

$$
T_{5} \equiv T_{\varphi=2 \pi}=T_{3}^{*}-\frac{c_{5}^{2}}{\frac{2 \cdot k \cdot R}{k+1}}
$$

lub:

$$
T_{5}=\tau\left(\lambda_{5}\right) \cdot T_{5}^{*}
$$

gdzie, funkcja gazodynamiczna temperatury

$$
\tau\left(\lambda_{5}\right)=1-\frac{k-1}{k+1} \lambda_{5}^{2}
$$

- Praca strat tarcia w kolektorze poprzedzonym dyfuzorem bezłopatkowym

$$
l_{r 3,5}=\xi_{s p} \frac{c_{3}^{2}}{2}
$$

- Wykładnik politropy sprężania w kolektorze $\mathrm{n} \equiv \mathrm{n}_{3,5}$ wyznacza się z zależności (I Z.T.):

$$
l_{r 3,5}=\left(\frac{k}{k-1}-\frac{n}{n-1}\right) R\left(T_{5}-T_{3}\right)
$$


lub z równania politropy:

$\frac{n}{n-1}=\frac{\ln \frac{p_{5}}{p_{3}}}{\ln \frac{T_{5}}{T_{3}}}$

zazwyczaj $n=1,9 \div 2,0$

- Promień jednostrumieniowego kolektora kołowego na wylocie - dla $\varphi=2 \pi \mathrm{z}$ formuły (11) wynika bezpośrednio

$$
r_{5}=\frac{\dot{m}}{2 \pi \cdot K \cdot \rho_{3}}+\sqrt{\frac{R_{3} \cdot \dot{m}}{\pi \cdot K \cdot \rho_{3}}}
$$

- Promień osi spirali na wylocie

$$
R_{s r 5}=R_{3}+r_{5}
$$

Sprawdzenie wartości promienia jednostrumieniowego kolektora kołowego na wylocie może przebiegać w następującej kolejności:

- Ciśnienie statyczne

$$
p_{5}=p_{3}\left(\frac{T_{5}}{T_{3}}\right)^{\frac{n}{n-1}}
$$

- Stopień strat ciśnienia spiętrzenia w kolektorze

$$
\sigma_{3,5}=1-\xi_{s p} \frac{k \cdot \lambda_{3}^{2}}{k+1}\left(1-\frac{k-1}{k+1} \lambda_{3}^{2}\right)^{\frac{k}{k-1}}
$$

- Ciśnienie spiętrzenia

$$
p_{5}^{*}=\sigma_{3,5} \cdot p_{3}^{*}
$$

- Względna gęstość strumienia masy

$$
q\left(\lambda_{5}\right)=\lambda_{5}\left(1-\frac{k-1}{k+1} \lambda_{5}^{2}\right)^{\frac{k}{k-1}}\left(\frac{k+1}{2}\right)^{\frac{k}{k-1}}
$$

- Przekrój kolektora

$$
F_{5}=\frac{\dot{m} \sqrt{T_{5}^{*}}}{s \cdot p_{5}^{*} \cdot q\left(\lambda_{5}\right)}
$$

gdzie, stała w równaniu ciągłości 
Dla powietrza: $s=0,0404\left(\frac{J}{k g K}\right)^{-0,5}$

- Promień jednostrumieniowego kolektora na wylocie

$$
r_{5}=\sqrt{\frac{F_{5}}{\pi}}
$$

\section{Uwagi końcowe}

Przedstawione w pracy rozważania dotyczące doboru powierzchni przekrojów promieniowych $F=F(\varphi)$ dla typowych kształtów kolektorów przebiegały w oparciu o model czynnika nielepkiego - równanie (5). Jednakże straty występujące w kolektorze powodują odpowiednie spadki ciśnienia. Według B. Eckerta [9] zaleca się stosowanie dodatkowego opóźnienia czynnika, czyli dodatkowego powiększenia przekrojów promieniowych $F$, aby w ten sposób uwzględnić wpływ tarcia oraz oderwań w strefie języczka spirali $\left(\operatorname{od} \varphi=0\right.$ do $\left.\varphi=\varphi_{0}\right)$.

Odnośnie przytoczonej metody projektowania kolektorów nie ma jednak jednolitego poglądu, bowiem np. badania W. Kramera przedstawione w pracy [17] dyfuzorów spiralnych wykazują, że kolektory zaprojektowane w oparciu o model czynnika nielepkiego pracują najlepiej. Dlatego wydaje się, że nieco bezpieczniej jest przyjąć zasadę projektowania kolektorów na podstawie równania (7) i nie wprowadzać korekt wynikających ze strat ciśnienia, choć metoda B. Eckerta jest również dopuszczalna i poprawna. Obliczone parametry kolektora zaleca się zestawić w tabeli zbiorczej np. dla kolektora o przekroju kołowym.

Przepływ przez dyfuzor spiralny można traktować w pewnym stopniu jak przepływ przez kanał zakrzywiony. Podobnie, jak w każdym przepływie, w tego typu kanale powstają przepływy wtórne (indukowane, kolanowe) zaznaczone schematycznie na rysunku $12 \mathrm{z}$ prawej strony. Przepływ przez te dyfuzory był badany eksperymentalnie przez Krantz'a przy użyciu cieczy jako czynnika roboczego. W efekcie tych badań stwierdzono, iż torami cząstek nie są linie spiralne, lecz śrubowe. To powoduje, że droga, którą przepływający czynnik pokonuje jest kilkakrotnie większa od długości osi kolektora [10, 17].

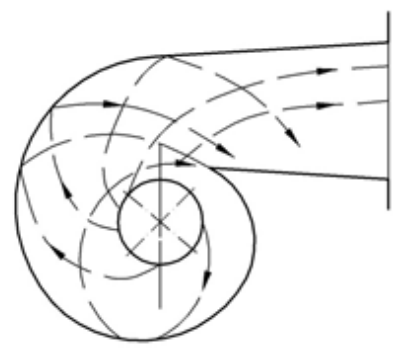

Rys. 12. Przepływ czynnika przez kolektor [9]

Fig. 12. Agent flow through the collector [9] 
W przypadku kolektorów symetrycznych wprowadzenie symetryczne strugi wypływającej z dyfuzora bezłopatkowego lub łopatkowego, a więc w kierunku środkowej linii, intensyfikuje przepływ wtórny i równocześnie powiększa straty. Jeżeli natomiast wypływający z dyfuzora strumień wprowadza się stycznie do kolektora (rys. 13), to przy jednostronnie ukształtowanym dyfuzorze spiralnym można zredukować wir podwójny do wiru pojedynczego, który powoduje mniejsze straty [9].

Rysunek 14 przedstawia charakterystyki stopnia sprężarki promieniowej $\mathrm{z}$ trzema różnymi kolektorami ukształtowanymi symetrycznie (dyfuzory spiralne a i b) i asymetrycznie (kolektor c). Z badań eksperymentalnych firmy Escher-Wyss wynika wniosek, że kolektory $\mathrm{z}$ asymetrycznym doprowadzeniem strumienia pracują z niższymi stratami, stąd tego rodzaju rozwiązania, jeśli brak innych względów - konstrukcyjnych lub technologicznych, zaleca się stosować w sprężarkach odśrodkowych.

Zagadnienie asymetrycznego doprowadzenia czynnika do kolektora było przedmiotem nielicznych badań teoretycznych i eksperymentalnych. Według autora pracy [17] kształty przekrojów promieniowych kanału kolektora spełniające warunek symetrycznego i asymetrycznego doprowadzenia czynnika są równoważne pod względem pracy sprężarki odśrodkowej. Należy jednak zauważyć, że kolektor asymetryczny w przypadku kształtu prostokątnego lub kwadratowego (rys. 15) nie tworzy dodatkowych problemów konstrukcyjnych, zaś

w dyfuzorze o zarysie kołowym asymetria doprowadzenia czynnika powoduje powstanie progu o wysokości $\Delta$ - rys. $15 b[7,13]$.

Rys. 13. Linie prądu w przekroju poprzecznym kolektora niesymetrycznego [17]

Fig. 13. The lines of current in the cross-section of the asymmetrical collector [17]

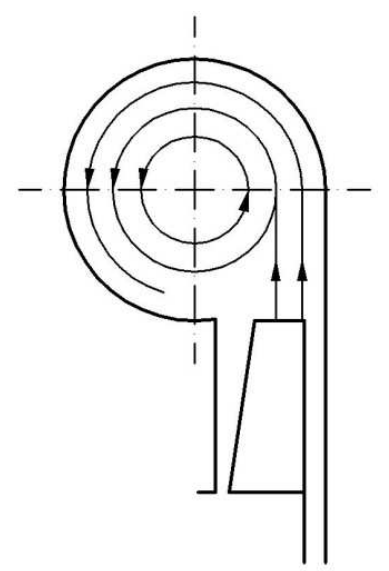



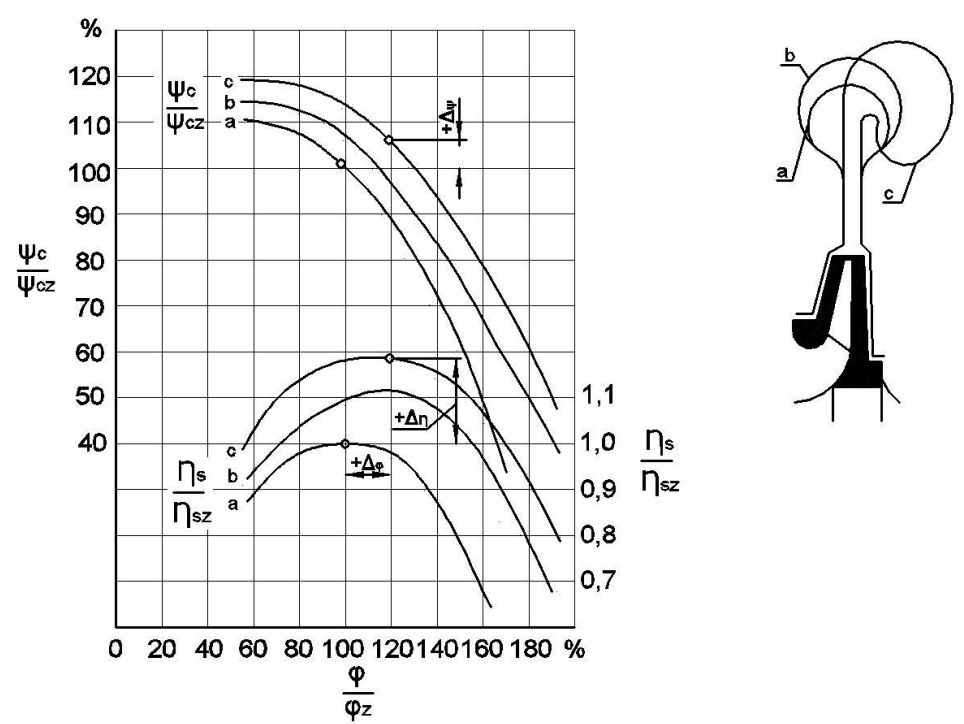

Rys. 14. Wpływ kształtu kolektora na charakterystykę i sprawność stopnia sprężarki promieniowej (badania Wytwórni Escher-Wyss Zurich); $\psi_{c}$ wskaźnik spiętrzenia całkowitego, $\eta_{S}$ - sprawność izentropowa, $\varphi$ - wskaźnik prędkości (indeks $z$ odnosi się do znamionowych warunków pracy) [9]

Fig. 14. Effect of the collector shape on characteristics and efficiency of compression ratio of the radial compressor (results of Escher-Wyss Zurich); $\psi_{c}$ - the index of total accumulation, $\eta_{S}$ - isentropic efficiency, $\varphi$ - speed index (subscript $z$ refers to the nominal operating conditions) [9]

a)

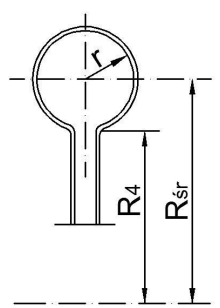

b)

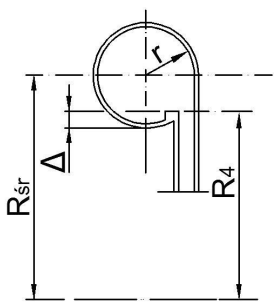

c)

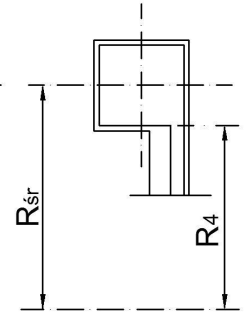

Rys. 15. Oznaczenie wielkości geometrycznych kolektora o zarysie kołowym symetrycznego (a), asymetrycznego (b) oraz asymetrycznego o przekroju kwadratowym (c)

Fig. 15. Designation of geometrical parameters of the collector with a circular contour: symmetric (a), asymmetric (b) and asymmetric with a rectangular section (c)

Promień osi spirali symetrycznej o zarysie kołowym, poprzedzonej dyfuzorem topatkowym wynosi wedtug wzoru (14) $\mathrm{R}_{\mathrm{sr}}=\mathrm{R}_{4}+\mathrm{r}$, stąd różnica:

$$
R_{s r}-r=R_{4}
$$


ma wartość stałą.

W przypadku asymetrycznego dyfuzora spiralnego o przekroju kołowym powyższe równanie nie jest spełnione, bowiem wysokość progu:

$$
\Delta=R_{4}-\left(R_{s r}-r\right)
$$

zaś według badań autorów pracy [13] różnica $\left(R_{s}-r\right)$ jest funkcją liniową kąta środkowego $\varphi^{\circ}$ wyrażonego w stopniach, tzn.:

$$
\left(R_{s r}-r\right)=a+b \varphi^{\circ}
$$

gdzie stałe: $\mathrm{a}=0,0823 \mathrm{~m}, \mathrm{~b}=2,3310^{-5} \mathrm{~m} /{ }^{0}$

\section{Literatura}

[1] Abdurasziłow S.A. [i in.]: Nasosy i kompriessory, Niedra, Moskwa 1974.

[2] Antas S.: Ocena wpływu wybranych metod modyfikacji maszyn wirnikowych turbinowych silników śmigłowych i śmigłowcowych na zapas statecznej pracy sprężarki. OW Politechniki Rzeszowskiej. Rzeszów 2006.

[3] Aungier R.H.: Centrifugal Compressors, ASME Press, New York 2000.

[4] Balje O.E.: Turbomachines. A Guide to Design. Selection and Theory, Wiley and Sons, New York 1981.

[5] Biełousow A.N., Musatkin N.F., Radko W.M.: Teorija i rasczot awiacionnych łopatocznych maszyn, Samarskij Gos. Aerokosm. Inst., Samara 2003.

[6] Cholscewnikow K.W.: Teorija i rasczot awiacyonnych łopatocznych maszin, Maszinostrostrojenije, Moskwa 1970.

[7] Cumpsty N.A.: Compressor aerodynamics, Longman Scientifics and Technical, Singapore 1989.

[8] Dmitriewskij W.I.: Gazodinamiczeskij rasczot i profilirowanije stupieni centrobieżnowo kompresora, Techniczeskij otczet No. 137, CiAM, Moskwa 1960.

[9] Eckert B.: Sprężarki osiowe i promieniowe. Zastosowanie, teoria, obliczanie, PWT, Warszawa 1959.

[10] Hariharan C., Govardhan M.: Effect of inlet clearance on the aerodynamic performance of centrifugal blower, Int. J. Turbo Jet Engines, 33 (2015) 215-228.

[11] Japikse D.: Centrifugal Compressor Design and Performance, Concepts ETI, Inc., 1996.

[12] Japikse D.: Centrifugal Compressor Design and Performance, Concepts ETI, Inc. Norwich, Vermont, Course held at Borsing GmbH Berlin, Germany, September 1990.

[13] Pan D., Whitfield A., Wilson M.: Design considerations for the volutes of centrifugal fans and compressors, IMechE Paper C06997, 213 (1999) 401-410.

[14] Podobujew Ju.S., Selezniew K.P.: Teorija i rasczot osiewnych i centrobieżnych kompriessorow, Maszgiz, Moskwa-Leningrad 1957. 
[15] Reunanen A.: Experimental and numerical analysis of different volutes in a centrifugal compressor, D.Sc. Thesis, Lappeemranta University of Technology 2001.

[16] Ris W.F.: Centrobieżnye kompressornye maszyny, Maszgis, Leningrad, 1951.

[17] Tuliszka E.: Sprężarki, dmuchawy i wentylatory, WNT, Warszawa 1976.

[18] Van den Braembusshe R.A., Hände B.M.: Experimental and theoretical study of the swirling flow in centrifugal compressor volutes, Trans. ASME, J. Turbomachinery, 112 (1990) 38-43.

[19] Walczak J.: Sprężarki i dmuchawy promieniowe. Teoria, badania i optymalizacja stopnia sprężającego, Wydawnictwo Poznańskiego Towarzystwa Przyjaciół Nauk, Poznań 1999.

[20] Witkowski A.: Sprężarki wirnikowe. Teoria, konstrukcja, eksploatacja, Wydawnictwo Politechniki Śląskiej, Gliwice 2004.

[21] Yahya S.M.: Turbines compressors and fans, Fourth edition, Tata McGraw Hill Education Private Limited, New Delhi 2012.

\title{
METHODS FOR CALCULATION OF COLLECTOR PARAMETERS APPLIED TO THE CONCEPTUAL DESIGN OF RADIAL COMPRESSOR
}

\begin{abstract}
S u m m a r y
In many constructions of one-stage radial and axial-centrifugal compressors of the turboprop and turboshaft aviation engines, a properly formed collector placed after vaneless or vane radial diffuser in order to decrease velocity and to increase air stream static pressure is applied. The spiral diffuser is one of the fundamental diffuser type. A volute is a channel with a different form of traverse sections that gradually expands in a direction of rotor rotational speed and encloses previous diffuser with a cylindrical intake hole. Its geometrical parameters should be properly selected to ensure the correct operation of the scroll. This paper presents two fundamental methods of calculation of geometrical parameters of the spiral diffuser: free vortex design (constant angular momentum principle) and constant mean velocity design. Mentioned methods (for conceptual design of a compressor) are based on energy equation - steady flow energy equation, equation of continuity, first law of thermodynamics, Euler's moment of momentum equation, gas dynamics functions and definitions used in theory of turbomachinery. Detailed analysis of geometrical parameters of different types of collectors was conducted. This paper also provides a review of experimental research results of total pressure loss coefficient in the volute and proposed method of determining air stream parameters at volute outlet.
\end{abstract}

Keywords: turbine engine, compressor, collector

DOI: $10.7862 / \mathrm{rm} .2016 .22$

Otrzymano/received: $14.10 .2016 r$.

Zaakceptowano/accepted: 15.11.2016r. 